\title{
Influence of High Concentrations of Copper Sulfate on In Vitro Adventitious Organogenesis of Cucumis sativus L.
}

\author{
Jorge Fonseca Miguel ${ }^{1,}$, \\ 1 Department of Biotechnology, Universidad Politécnica de Valencia, Instituto de Biología Molecular y Celular \\ de Plantas (IBMCP), Ingeniero Fausto Elio s/n, 46022 Valencia, Spain; jfonseca@doctor.upv.es
}

\begin{abstract}
The effects of different concentrations of copper sulfate $\left(0.2\right.$ to $\left.5 \mathrm{mg} \mathrm{L}^{-1}\right)$ on in vitro callus and shoot formation of cucumber was investigated. Four-day-old cotyledon explants from the inbred line 'Wisconsin 2843' and the commercial cultivars 'Marketer' and 'Negrito' were used. The results on callus-derived shoots showed that the optimal concentration of $\mathrm{CuSO}_{4}$ added to Murashige \& Skoog (MS)-derived shoot induction medium containing $0.5 \mathrm{mg} \mathrm{L}^{-1} \mathrm{IAA}$ and $2.5 \mathrm{mg} \mathrm{L}^{-1}$ BAP was 8200 fold greater than in standard MS medium, and was genotype dependent. The highest genotypes response on shoot frequency and shoot number was achieved in this order by 'Marketer', 'Negrito' and 'Wisconsin 2843' with $1,0.2$ y $5 \mathrm{mg} \mathrm{L}^{-1} \mathrm{CuSO}_{4}$, respectively. The genotype with the lowest control performance demanded the highest concentration of $\mathrm{CuSO}_{4}$ for its optimal morphogenic response - 6- and 10-fold more in shoot frequency and shoot number, respectively. The other cultivars registered a 2-fold increase in both variables. All explants formed callus and the response on callus extension varied among cultivars. The regression analysis showed a statistically significant relationship between shoot number and concentrations of $\mathrm{CuSO}_{4}$ and absence of association with callus extension. The present results indicate that application of specific concentrations of $\mathrm{CuSO}_{4}$ higher than in standard MS medium, increases adventitious cucumber shoot organogenesis.
\end{abstract}

Keywords: copper sulfate; morphogenesis; shoot regeneration; cotyledon explant; Cucurbitaceae

\section{Introduction}

Cucumber (Cucumis sativus L.) belongs to the Cucurbitaceae family. This species is an economically important vegetable crop and a model plant for sex determination and vascular biology studies (Huang et al., 2009). According to the Food and Agriculture Organization of the United Nations (FAO), in 2019, the world production of cucumbers, including gherkins, ranked third among vegetable crops with $87,805,086$ tonnes, and a harvested area of 2,231,402 hectares (FAOSTAT, http://www.fao.org/faostat/en/\#data/QC). Crop improvement of cucumber for resistance/tolerance against major biotic and abiotic stresses is difficult by conventional breeding due to its narrow genetic base, a genetic variability of only 3-8\% (Plader et al., 2007), and several crossing barriers with related species (den Nijs and Custers, 1990). Applying genetic engineering and plant transformation technologies make it possible to overcome these limitations and to develop cultivars with value-added traits.

Despite the number of publications on genetic transformation of cucumber (for reviews, see Yin et al., 2005; He et al., 2008; Wang et al, 2015; Miguel, 2017), with Agrobacterium-mediated gene 
bioRxiv preprint doi: https://doi.org/10.1101/2021.02.24.432794; this version posted February 25, 2021. The copyright holder for this preprint (which was not certified by peer review) is the author/funder, who has granted bioRxiv a license to display the preprint in perpetuity. It is made available under aCC-BY 4.0 International license.

transfer as the most commonly used, and reliable method, its efficiency is still very low (Wang et al., 2015; Miguel, 2017). One of the main problems in obtaining transgenic cucumber plants is related to regeneration, i.e. low morphogenic response in explants of certain genotypes, and decrease in the regeneration rate as a result of the usual transformation steps (Miguel, 2017). A reliable plant genetic transformation system demands an efficient and stable regeneration procedure (Yin et al., 2005; He et al., 2008; Wang et al., 2015). In almost all practical transformation systems, tissue culture is employed to achieve a workable efficiency of genetic transfer, selection and regeneration of transformants (Birch, 1997).

In vitro regeneration of cucumber can be achieved by using different tissue culture approaches (Malepszy, 1988). Regeneration via organogenesis and somatic embryogenesis in this species has been described using a variety of explants, namely cotyledons (Trulson and Shahin, 1986; Chee, 1990; Gambley and Dodd, 1990; Punja et al., 1990a; Ali et al., 1991; Lou and Kako. 1994; Selvaraj et al., 2007; Grozeva and Velkov, 2014), hypocotyls (Ziv and Gadasi, 1986; Chee, 1990; Selvaraj et al., 2006; Grozeva and Velkov, 2014), leaves (Malepszy and Nadolska-Orczyk, 1983; Punja et al. 1990a; Lou and Kako. 1994; Burza and Malepszy, 1995a; Seo et al., 2000), and petiols (Punja et al. 1990a). Regeneration of cucumber has also been reported from protoplasts (Trulson and Shahin, 1986; Punja et al., 1990b; Burza and Malepszy. 1995b), and suspension cultures (Chee and Tricoli, 1988: Raharjo and Punja, 1994; Kreuger et al., 1996). Cucumber regeneration is largely dependent on genotype, explant type, and culture medium (Wehner and Locy, 1981; Trulson and Shahin, 1986; Punja et al. 1990a; Grozeva and Velkov, 2014; Li et al., 2016). Although in vitro plant regeneration of cucumber has been extensively reported, a high regeneration system for this species is still below the expected (Wang et al., 2015).

Inorganic macro- and micronutrients levels widely used in plant tissue culture media are based on those of Murashige and Skoog (1962) (MS) medium, developed for tobacco. However, for many of its micronutrients a clear optimal level was not evident. Furthermore, tissue culture of non-tobacco species may require a different concentration of its micronutrients for optimal response (Dahleen, 1995). Heavy metals such as copper (Cu), iron (Fe), manganese (Mn), molybdenum (Mo), nickel $(\mathrm{Ni})$, and zinc $(\mathrm{Zn})$ are essential plant micronutrients that are required in small but critical amounts for its normal growth and development (Alloway, 2013; Arif et al., 2016).

$\mathrm{Cu}$ is a redox-active transition element that is involved in many physiological processes in plants (Yruela, 2005). Its role as redox agent also makes it potentially toxic, as $\mathrm{Cu}$ ions can catalyse the production of damaging free radicals (Tomar et al., 2015). Cu acts as a structural component of numerous proteins and as a cofactor for many enzymes, including plastocyanin, cytochrome c oxidase, ascorbate oxidase, laccase, Cu/Zn superoxide dismutases (SODs), polyphenol oxidases, copper-containing amine oxidases, and phytohormone receptors. Cu plays a role in a wide range of processes such as photosynthetic electron transport, mitochondrial respiration, carbohydrate and nitrogen metabolism, cell wall metabolism, oxidative stress response, disease resistance, pollen viability, water permeability of xylem vessels, and hormone signaling (for reviews, see Yruela, 2009; Cohu and Pilon, 2010; Kabata-Pendias, 2010; Broadley et al., 2012; Tripathi et al., 2015; Migocka and Malas, 2018). Either deficient or in excess, it can cause disorders in plant growth and development (Yruela, 2009). Its deficiency leads to defects in photosynthesis, reduced respiration, chlorosis, and wilting of leaves (Shahbaz and Pilon, 2019), among others. Due to its relatively low 
bioRxiv preprint doi: https://doi.org/10.1101/2021.02.24.432794; this version posted February 25, 2021. The copyright holder for this preprint (which was not certified by peer review) is the author/funder, who has granted bioRxiv a license to display the preprint in perpetuity. It is made available under aCC-BY 4.0 International license.

mobility in plants, young organs are usually the first to develop Cu-deficiency symptoms (KabataPendias, 2010). Cu levels in cells should be kept low, since this element is extremely toxic (due to its high redox properties) (Yruela, 2009). The most common symptoms of its toxicity are low photosynthesis efficiency, damage to DNA, disturbed protein complexes, damage to membrane permeability, chlorosis, and root malformation (Kabata-Pendias and Szteke, 2015).

It has been reported by different authors a positive effect of higher levels of copper in in vitro culture and morphogenesis of different plant species, namely in melon (Garcia-Sogo et al., 1991), watermelon (Ellul, 2002), carrot (Kowalska et al., 2012), indian ginseng (Sinha et al., 2010), tobacco (Purnhauser and Gyulai, 1993), tetraploid wheat (Ghaemi et al., 1994), hexaploid wheat (Purnhauser and Gyulai, 1993), triticale (Purnhauser and Gyulai, 1993), barley (Dahleen, 1995), indica rice (Sahrawat and Chand, 1999), sorghum (Nirwan and Kothari, 2003), bamboo (Singh et al., 2017), and date palm (Al-Mayahi, 2014). Nonetheless, negative effects of excessive exposure to this micronutrient have also been reported (e.g. Garcia-Sogo et al. (1991) in melon, Purnhauser and Gyulai (1993) in tobacco, and Ghaemi et al. (1994) in tetraploid wheat). To our knowledge, this is the first report on the effect of high concentration of copper ion on in vitro adventitious regeneration of cucumber.

The aim of the present work was to evaluate the influence of different concentrations of $\mathrm{CuSO}_{4}$ on in vitro adventitious organogenesis, using cotyledon as explants from one inbreed line and two commercial cultivars of cucumber.

\section{Materials and Methods}

\subsection{Plant material and in vitro regeneration}

Cucumber seeds from inbred line 'Wisconsin 2843' (kindly provided by Dr. C.E. Peterson, Michigan State University, East Lansing, USA), and cultivars 'Marketer' and 'Negrito' (Semillas Fitó S.A.) were used as starting material. Mature seeds were decoated and surface-sterilized by immersion in a diluted commercial bleach ( $5 \% \mathrm{w} / \mathrm{v}$ sodium hypochlorite) with 0.1 (v/v) $7 \mathrm{X}-\mathrm{O}-\mathrm{matic}$ (Flow Laboratories) for $30 \mathrm{~min}$. The seeds were then rinsed three times with sterile distilled water for 5,10 and $15 \mathrm{~min}$, respectively. After sterilization, the seeds were germinated in the dark $(150 \mathrm{~mm} \mathrm{x}$ $25 \mathrm{~mm}$ test tubes) on solid germination medium (GM), consisting of Murashige and Skoog's (1962) inorganic basal salts supplemented with $1 \%(\mathrm{w} / \mathrm{v})$ sucrose, and $0.8 \%(\mathrm{w} / \mathrm{v})$ agar (Industrial, Pronadisa), and its $\mathrm{pH}$ adjusted to 5.7 prior to autoclaving at $115{ }^{\circ} \mathrm{C}$ for $30 \mathrm{~min}$. After 1 to 2 days, when the radicle emerged and curved into the medium, the test tubes were transferred to a tissue culture chamber maintained at $26 \pm 2{ }^{\circ} \mathrm{C}$ with a $16 \mathrm{~h}$ photoperiod under cool-white fluorescent lamps (Grolux, Sylvania), and with a light intensity of 2000 lux. The same incubation conditions were used in the subsequent in vitro culture steps. Cotyledons from four-day-old seedlings were used as explant source by excising transversely $1-2 \mathrm{~mm}$ beyond its proximal and distal ends. The experimental assessments are based on naked-eye observations.

Cotiledonary explants were cultured for 3 weeks in $300 \mathrm{ml}$ glass jars with the abaxial side in contact with the shoot induction medium (SIM), containing Murashige and Skoog's (1962) inorganic basal salts supplemented with $3 \%(\mathrm{w} / \mathrm{v})$ sucrose, $0.1 \mathrm{~g} \mathrm{~L}^{-1}$ myo-inositol, $1 \mathrm{mg} \mathrm{L}^{-1}$ thiamine-HCl, RT vitamins (Staba, 1969), $0.5 \mathrm{mg} \mathrm{L}^{-1}$ Indole-3-acetic acid (IAA), $2.5 \mathrm{mg} \mathrm{L}^{-1} 6$-benzylaminopurine (BAP), and copper sulfate as $\mathrm{CuSO}_{4} \cdot 5 \mathrm{H}_{2} \mathrm{O}\left(0.0,0.2,1.0\right.$ and $\left.5.0 \mathrm{~g} \mathrm{~L}^{-1}\right)$, in addition to its standard 
bioRxiv preprint doi: https://doi.org/10.1101/2021.02.24.432794; this version posted February 25, 2021. The copyright holder for this preprint (which was not certified by peer review) is the author/funder, who has granted bioRxiv a license to display the preprint in perpetuity. It is made available under aCC-BY 4.0 International license.

concentration of MS $\left(0.025 \mathrm{mg} \mathrm{L}^{-1}\right)$. The medium was solidified with $0.8 \%(\mathrm{w} / \mathrm{v})$ agar (Industrial, Pronadisa) and its $\mathrm{pH}$ adjusted to 5.7 before autoclaving. At the end of this phase, the evaluation on callus regeneration frequency (\%) (CRF) and callus extension index (CEI) was performed. The CRF (mean \pm SE) was calculated by the frequency of explants with callus formation in the cutting zone (proximal and distal edges); the CEI (mean \pm SE) was measured by the mean value corresponding to arbitrary values (from 0 to 3 ) on the extension of callus formation for each explant, whereas: $0=$ absence of callus on the cutting zone; $1=$ traces of callus on the cutting zone; 2 = callus on less than half of the cutting zone; $3=$ callus on half or more of the cutting zone; $4=$ callus covering the full extension of the cutting zone.

Adventious buds and shoot primordia were then transferred to $300 \mathrm{ml}$ glass jars containing shoot development and elongation medium (SDM) where auxins were not included and BAP was substituted by $0.2 \mathrm{mg} \mathrm{L}^{-1} \mathrm{KIN}$. After 2 weeks of culture, the response on shoot regeneration frequency (SRF) and shoot number index (SNI) was determined. The SRF (mean \pm SE) was calculated by the frequency of explants with shoot formation; the SNI (mean \pm SE) was measured by the mean value corresponding to arbitrary values (from 0 to 3 ) on the number of shoot formation for each explant, whereas: $0=$ absence of any shoot; $1=$ one shoot; $2=2$ shoots; $3=3$ or more shoots. Individualized shoots were further rooted on hormone-free MS medium and within 3 to 4 weeks, the plantlets were ready for acclimatization (data not shown).

\subsection{Data analysis}

The experimental design was a two-way factorial arrangement $3 \times 4$ on a completely randomized design, with at least 11 replicate jars per treatment with 6 explants per jar. Treatment means comparison were assessed by non-linear regression analyses. Count data variables, i.e. callus extension index (CEI) and shoot number index (SNI) were submitted to generalized poisson regression and negative binomial regression analyses, respectively. Logistic regression was performed for data collected as binary values. Relationships between SNI (response variable) and the predictors ( $\mathrm{CEI}, \mathrm{CuSO}_{4}$ concentration) were analyzed using generalized poisson regression. All statistics were performed using R 3.4.4 software (R Core Team, 2018). The R packages 'stats' ( $R$ Core Team, 2018), 'VGAM' (Yee, 2019), and 'MASS' (Venables and Ripley, 2002) were used to perform logistic regression, negative binomial regression, and generalized poisson regression, respectively. Dispersion test was performed using the 'AER' package (Kleiber and Zeileis, 2008), in order to test the suitability of applying Poisson GLMs to our count data. Binary data were tested for overdispersion by fitting the model twice, i.e., firstly using a binomial family, and then a quasibinomial family, and by using the 'pchisq' function (Kabacoff, 2011) from the 'stats' package, indicating a lack of overdispersion. Multicollinearity between predictors was assessed by calculating the generalized variation inflation factor (GVIF; Fox and Monette, 1992) for each predictor, using the 'vif' function in the 'car' package (Fox and Weisberg, 2011), indicating that multicollinearity was not a problem in the present analyses (GVIFs<1.24). The 'rockchalk' package (Johnson, 2019) was used to combine levels not significantly different from each other in the analysis of the association between variables. Model performance was evaluated using Akaike Information Criterion (AIC; Akaike, 1973) and Bayesian Information Criterion (BIC; Schwarz, 1978), and the best fitting model was selected based on the lowest AIC and BIC values. The Wald test was used in regression to test 
bioRxiv preprint doi: https://doi.org/10.1101/2021.02.24.432794; this version posted February 25, 2021. The copyright holder for this preprint (which was not certified by peer review) is the author/funder, who has granted bioRxiv a license to display the preprint in perpetuity. It is made available under aCC-BY 4.0 International license.

for significance. A probability value of $P<0.05$ was used as the criterion for statistical significance for all analyses.

\section{Results}

\subsection{Frequency and extension of callus}

The results are shown in Table 1. Statistics numerical data are expressed as mean \pm standard error of the mean (SEM). The formation of callus occurred in the first 2 weeks of culture, starting from the cut edges of the primary explants. All treatments recorded $100 \%$ callus regeneration frequency. Data collected as arbitrary values were submitted to regression analysis. Callus extension index (CEI) showed significant differences in two of the three cultivars of cucumber for 'CuSO ${ }_{4}$ concentration' $(P<0.05)$. The response in $\mathrm{CEI}$, ranked from highest to lowest, varied as follows: for 'Marketer', from 2.60 $\pm 0.06\left(0.2 \mathrm{mg} \mathrm{L}-1 \mathrm{CuSO}_{4}\right)$ to $2.91 \pm 0.05\left(0 \mathrm{mg} \mathrm{L}-1 \mathrm{CuSO}_{4}\right)$; for 'Negrito', with no significant differences, from $2.52 \pm 0.07$ (1.0 mg L-1 $\left.\mathrm{CuSO}_{4}\right)$ to $2.70 \pm 0.06$ (0.2 mg L$\left.1 \mathrm{CuSO}_{4}\right)$; and for 'Wisconsin 2843', from 2.03 $\pm 0.02\left(5.0 \mathrm{mg} \mathrm{L}-1 \mathrm{CuSO}_{4}\right)$ to $2.52 \pm 0.06(1.0 \mathrm{mg} \mathrm{L}-1$ $\left.\mathrm{CuSO}_{4}\right)$. These results are between the arbitrary values of 2: callus on less than half of the cutting zone, and 3: callus on half or more of the cutting zone. In virtually all cases, the order of magnitude of the $\mathrm{CEI}$ response of cultivars to the $\mathrm{CuSO}_{4}$ concentration was different. In the control group, callus of the 'Wisconsin 2843' line contrasts with the lighter and more friable callus of the 'Marketer' and 'Negrito' cultivars. With the addition of high concentrations of $\mathrm{CuSO}_{4}$, the callus generally became more compact and greenish (data not shown).

\subsection{Frequency and number of shoots}

Results are presented as mean \pm SEM (Table 1). Significance was set at $P<0.05$. At $1.5-3$ weeks of culture, groups of adventitious buds emerge especially at the proximal end of the explant, which at 2-4 weeks under cultivation could give rise to shoot primordia. Binary and count-data variables, i.e. shoot regeneration frequency (\%) (SRF) and shoot number index (SNI), respectively, were subjected to regression analysis. Both variables revealed significant differences in all the three cultivars of cucumber for ' $\mathrm{CuSO}_{4}$ concentration'. For 'Wisconsin 2843', both SRF and SNI tended to increase with increasing concentration of $\mathrm{CuSO}_{4}$; the highest SRF (16.67 \pm 4.42$)$ and SNI $(0.31 \pm 0.09)$ was obtained for the medium supplemented with $5.0 \mathrm{mg} \mathrm{L}-1 \mathrm{CuSO}_{4}$, resulting in 6- and 10.3-fold higher, respectively, than the control. In the case of 'Marketer' both variables increased with increasing concentration of $\mathrm{CuSO}_{4}$ up to $1.0 \mathrm{mg} \mathrm{L}-1$, but thereafter decreased significantly as the concentration increases; the maximum SRF $(50.00 \pm 5.93)$ and SNI $(0.76 \pm 0.11)$ resulted in 1.7 - and 2.2-fold greater, respectively, when compared to the control. In relation to 'Negrito' both variables increased with $0.2 \mathrm{mg} \mathrm{L}-1$ of $\mathrm{CuSO}_{4}$, but thereafter decreased significantly as the concentration increases; the highest SRF $(42.42 \pm 6.13)$ and SNI $(0.61 \pm 0.10)$, resulted in 1.7- and 2-fold higher, respectively, than the control. All cultivars revealed significant differences between the medium with the highest response and the control. From the above results, the performance of the cultivars, ranked from highest to lowest, was as follows: 'Marketer'>'Negrito'>'Wisconsin 2843'. 
Table 1. Effect of the addition of different concentrations of copper sulfate to MS-derived shoot induction medium (SIM) containing $0.5 \mathrm{mg} \mathrm{L}-1$ IAA and $2.5 \mathrm{mg} \mathrm{L}-1$ BAP on in vitro callus and shoot regeneration from cotyledon explants of three cultivars of Cucumis sativus $L$. Values are expressed as mean \pm standard error of the mean.

\begin{tabular}{|c|c|c|c|c|c|c|}
\hline \multirow{2}{*}{$\begin{array}{l}\text { Cucumber } \\
\text { cultivar }\end{array}$} & \multicolumn{2}{|c|}{$\mathrm{CuSO}{ }_{4} .5 \mathrm{H}_{2} \mathrm{O}$} & \multirow{2}{*}{$\begin{array}{c}\text { Callus } \\
\text { regeneration } \\
\text { frequency } \\
(\%)^{*}\end{array}$} & \multirow{2}{*}{$\begin{array}{c}\text { Callus } \\
\text { extension } \\
\text { index }\end{array}$} & \multirow{2}{*}{$\begin{array}{c}\text { Shoot } \\
\text { regeneration } \\
\text { frequency }(\%)^{\S}\end{array}$} & \multirow{2}{*}{$\begin{array}{c}\text { Shoot } \\
\text { number } \\
\text { index }\end{array}$} \\
\hline & $\mathbf{m g} / \mathbf{l}$ & $\boldsymbol{\mu} \mathbf{M}$ & & & & \\
\hline \multirow[t]{4}{*}{ Wisconsin 2843} & 0.0 & 0.0 & 100.00 & $2.38 \pm 0.06^{\mathrm{ab}}$ & $2.78 \pm 1.95^{\mathrm{b}}$ & $0.03 \pm 0.02^{\mathrm{b}}$ \\
\hline & 0.2 & 0.8 & 100.00 & $2.19 \pm 0.05^{b}$ & $5.56 \pm 2.72^{b}$ & $0.07 \pm 0.04^{b}$ \\
\hline & 1.0 & 4.0 & 100.00 & $2.52 \pm 0.06^{\mathrm{a}}$ & $4.55 \pm 2.58^{b}$ & $0.06 \pm 0.04^{b}$ \\
\hline & 5.0 & 20.0 & 100.00 & $2.03 \pm 0.02^{c}$ & $16.67 \pm 4.42^{\mathrm{a}}$ & $0.31 \pm 0.09^{a}$ \\
\hline \multirow[t]{4}{*}{ Marketer } & 0.0 & 0.0 & 100.00 & $2.91 \pm 0.05^{\mathrm{a}}$ & $30.30 \pm 5.70^{b}$ & $0.35 \pm 0.07^{b}$ \\
\hline & 0.2 & 0.8 & 100.00 & $2.60 \pm 0.06^{b}$ & $37.50 \pm 5.75^{\mathrm{ab}}$ & $0.54 \pm 0.09^{\mathrm{ab}}$ \\
\hline & 1.0 & 4.0 & 100.00 & $2.67 \pm 0.06^{\mathrm{ab}}$ & $50.00 \pm 5.93^{a}$ & $0.76 \pm 0.11^{a}$ \\
\hline & 5.0 & 20.0 & 100.00 & $2.85 \pm 0.05^{\mathrm{ab}}$ & $26.76 \pm 5.29^{b}$ & $0.37 \pm 0.09^{b}$ \\
\hline \multirow[t]{4}{*}{ Negrito } & 0.0 & 0.0 & 100.00 & $2.54 \pm 0.06^{a}$ & $25.00 \pm 5.14^{b}$ & $0.31 \pm 0.07^{b}$ \\
\hline & 0.2 & 0.8 & 100.00 & $2.70 \pm 0.06^{\mathrm{a}}$ & $42.42 \pm 6.13^{\mathrm{a}}$ & $0.61 \pm 0.10^{\mathrm{a}}$ \\
\hline & 1.0 & 4.0 & 100.00 & $2.52 \pm 0.07^{\mathrm{a}}$ & $16.67 \pm 4.62^{b}$ & $0.20 \pm 0.06^{b}$ \\
\hline & 5.0 & 20.0 & 100.00 & $2.59 \pm 0.06^{\mathrm{a}}$ & $21.88 \pm 5.21^{b}$ & $0.31 \pm 0.08^{b}$ \\
\hline
\end{tabular}

${ }^{*, \pm}$ Data were scored after 3 weeks on the shoot induction medium (SIM).

${ }^{\S, \dagger}$ Data were scored after 2 weeks on the shoot development and elongation medium (SDM).

${ }^{\ddagger}$ Generalized poisson regression, ${ }^{\S}$ logistic regression, and ${ }^{\dagger}$ negative binomial regression were used for data analysis. Means in the same column followed by different letters are significantly different (Wald test, $P<0.05)$.

Table 2. Factors associated with shoot number index (SNI) in generalized poisson regression among three cultivars.

\begin{tabular}{|c|c|c|c|c|c|c|c|c|c|c|c|c|}
\hline \multirow[b]{2}{*}{ Factor } & \multicolumn{4}{|c|}{ Wisconsin 2843} & \multicolumn{4}{|c|}{ Marketer } & \multicolumn{4}{|c|}{ Negrito } \\
\hline & Estimate & $\begin{array}{l}\text { Std. } \\
\text { Error }\end{array}$ & $\begin{array}{c}z \\
\text { value }\end{array}$ & $\operatorname{Pr}(>|z|)^{\ddagger}$ & Estimate & $\begin{array}{l}\text { Std. } \\
\text { Error }\end{array}$ & $\begin{array}{c}z \\
\text { value }\end{array}$ & $\operatorname{Pr}(>|z|)$ & Estimate & $\begin{array}{l}\text { Std. } \\
\text { Error }\end{array}$ & $\begin{array}{c}\mathbf{z} \\
\text { value }\end{array}$ & $\operatorname{Pr}(>|z|)$ \\
\hline (Intercept):1 & 0,6098 & 0,2230 & 2,734 & $0,0063^{\star \star}$ & 0,1375 & 0,0911 & 1,510 & 0,1312 & 0,1798 & 0,1026 & 1,752 & 0,0797 \\
\hline (Intercept):2 & $-1,0613$ & 1,4088 & $-0,753$ & 0,4513 & 0,2753 & 0,4990 & 0,552 & 0,5812 & 0,3006 & 0,6007 & 0,500 & 0,6168 \\
\hline $\mathrm{CEI} I^{\S}$ & $-0,2816$ & 0,6831 & $-0,412$ & 0,6802 & $-0,2301$ & 0,1824 & $-1,262$ & 0,2071 & $-0,3351$ & 0,2193 & $-1,528$ & 0,1266 \\
\hline $\mathrm{CuSO}_{4}{ }^{\dagger}$ & $-1,4173$ & 0,4732 & $-2,995$ & $0,0027^{\star \star}$ & $-0,5829$ & 0,1843 & $-3,162$ & 0,0016 ** & $-0,8596$ & 0,2273 & $-3,783$ & $0,0002^{\star \star \star}$ \\
\hline DF & 560 & & & & 558 & & & & 532 & & & \\
\hline
\end{tabular}

* $P<0.05,{ }^{\star \star} P<0.01, \star \star \star * P<0.001$

${ }^{\ddagger}$ The Wald test was used for significance.

${ }^{8}$ Callus extension index.

${ }^{\dagger}$ Concentration of $\mathrm{CuSO}_{4}$ on MS-derived shoot induction medium (SIM). Levels not significantly different from each other were combined. The reference levels for 'Wisconson 2843', 'Marketer' and 'Negrito' cultivars were set to 5, 1 and $0.2 \mathrm{mg} \mathrm{L}-1 \mathrm{CuSO}_{4}$, respectively. 
bioRxiv preprint doi: https://doi.org/10.1101/2021.02.24.432794; this version posted February 25, 2021. The copyright holder for this preprint (which was not certified by peer review) is the author/funder, who has granted bioRxiv a license to display the preprint in perpetuity. It is made available under aCC-BY 4.0 International license.

\subsection{Relationship between variables}

The results are given in Table 2. The relationships between the variables were assessed through multiple regression analysis, with shoot number index (SNI) as the response variable, and callus extension index (CEI) and ' $\mathrm{CUSO}_{4}$ concentration' as the predictors. Statistical significance was defined as $\mathrm{P}<0.05$. No relationship was observed between $\mathrm{SNI}$ and $\mathrm{CEI}$ in all the three cucumber cultivars tested. On the contrary, a strong relationship was found between $\mathrm{SNI}$ and ' $\mathrm{CuSO}_{4}$ concentration' (Wisconsin 2843: $P=0.0027$; Marketer: $P=0.0016$; Negrito: $P=0.0002$ ).

\section{Discussion}

The purpose of this work was to evaluate the effect of different concentrations of copper sulfate on the organogenic response of several cucumber cultivars. Cooper is an essential plant micronutrient that is required at low concentrations. For instance, in the Murashige and Skoog's (1962) mineral solution, copper is added as copper sulfate at a concentration of $0.025 \mathrm{mg} \mathrm{L}-1$. Different studies on in vitro plant regeneration showed that MS basal medium could be optimized for a specific genotype by adjusting the concentration of some of its micronutrients (e.g. Dahleen, 1995; Sahrawat and Chand, 1999; Kothari-Chajer et al., 2008).

Most essential heavy metals are required in plants and animals for biochemical and physiological functions. They integrate various key enzymes and have major roles in different oxidation-reduction reactions (Nunes and Malmlöf, 2018). Heavy metals such as copper (Cu), iron $(\mathrm{Fe})$, manganese $(\mathrm{Mn})$, molybdenum (Mo), nickel $(\mathrm{Ni})$, and zinc $(\mathrm{Zn})$ are essential plant micronutrients that are required in very small amounts for its normal growth and development. Excessive levels of these elements within the plant tissue have different toxic effects, such as oxidative stress with further inhibition of cytoplasmic enzymes and damage to cellular structures, and a change on the uptake and accumulation of essential to non-essential elements, which affects enzymes and proteins function, and metabolisms (Arif et al., 2016).

In the present study, we observed that all explants formed callus and, the response on callus extension was dependent on the genotype and, in two of the three cultivars on the level of copper sulfate in the medium. Callus regeneration was usually observed in both proximal and distal zones of the cotyledon whereas shoot-buds were formed almost exclusively from the proximal part. This is in general agreement with other studies in cucurbits and other plants in which the proximal part of the cotyledon, adjacent to the cut edge of the explant, is the most active site for the regeneration of organized structures: cucumber (Gambley and Dodd, 1990; Msikita et al., 1990); melon (Gaba et al., 1999); horned melon (Lin et al., 2011); watermelon (Compton and Gray, 1993); squash (Ananthakrishnan et al., 2003); bottle gourd (Han et al., 2004); soybean (Hinchee et al., 1988); geranium (Chang et al., 1996). Cotyledon polarity on adventitious shoot regeneration is most likely the key factor for the absence of association between the number of shoots and the extension of callus, obtained for all cultivars.

The results on shoots regeneration showed dependence on the genotype and on the level of copper sulfate in the medium, indicating a possible interaction between the two factors. For both frequency (SRF) and number of shoots (SNI) the optimal concentration of $\mathrm{CuSO}_{4}$ was 8-200 fold higher than the control $\left(0.025 \mathrm{mg} \mathrm{L}^{-1}\right.$ - the standard MS concentration) and was cultivar-specific. Differences in the ability for callus formation and regeneration have been extensively reported 
bioRxiv preprint doi: https://doi.org/10.1101/2021.02.24.432794; this version posted February 25, 2021. The copyright holder for this preprint (which was not certified by peer review) is the author/funder, who has granted bioRxiv a license to display the preprint in perpetuity. It is made available under aCC-BY 4.0 International license.

among cucumber genotypes (e.g. Wehner and Locy, 1981; Grozeva and Velkov, 2014; see minireview by Wang et al., 2015), and within other species. Likewise, when high concentrations of copper were applied, differences have been reported within rice (Sahrawat and Chand, 1999), and barley (Dahleen, 1995), with the optimal concentration of the ion being cultivar-specific.

The positive effects of high concentrations of copper sulfate on in vitro adventitious shoot organogenesis of cucumber, are in line with those obtained with other cucurbits. Garcia-Sogo et al. (1991) found that levels of $\mathrm{CuSO}_{4}$ ranging from 0.1 to $5 \mathrm{mg} \mathrm{L}^{-1}$ on MS-based culture media resulted in a significant increase in callus-derived shoot-buds from cotyledon explants of melon. Ellul (2002) observed a positive response on the regeneration of watermelon from cotyledon explants when concentrations of $\mathrm{CuSO}_{4}$ ranging from 0.1 to $1.0 \mathrm{mg} \mathrm{L}^{-1}$ on MS-based culture media were used. The beneficial effects of high concentrations of copper on in vitro morphogenesis and regeneration are not exclusive to cucurbits. Ghaemi et al. (1994) found that levels of $\mathrm{CuSO}_{4}$ ranging from 2 to $10 \mathrm{mg}$ $\mathrm{L}^{-1}$ increased the production of embryoids from anthers in three of the four tetraploid wheat genotypes tested. Other studies reported that concentrations of $\mathrm{CuSO}_{4}$ ranging from 0.125 to $25 \mathrm{mg}$ L-1 significantly enhanced shoot and root regeneration in hexaploid wheat and triticale callus cultures initiated from immature embryos, shoot regeneration from leaf-disc cultures of tobacco (Purnhauser, 1991; Purnhauser and Gyulai, 1993), and plant regeneration from barley callus cultures derived from immature embryos (Dahleen, 1995). Callus growth and shoot regeneration in date palm callus cultures initiated from shoot apical meristem explants were significantly enhanced with $0.5 \mathrm{mg} \mathrm{L}^{-1} \mathrm{CuSO}_{4}$, and root regeneration by using $\mathrm{CuSO}_{4}$ at $0.125 \mathrm{mg} \mathrm{L}-1$ (Al-Mayahi, 2014). Optimal shoot regeneration from nodal explants of bamboo was achieved with the addition of $\mathrm{CuSO}_{4}$ five-fold higher than in MS medium (Singh et al., 2017). The enhancement of adventitious shoot formation with the application of high concentrations of copper sulfate was accompanied by an increase in the qualitative response, i.e., greener and more vigorous shoots (data not shown). Likewise, the presence of high levels of $\mathrm{CuSO}_{4}$ on adventitious regeneration of melon (Souza et al., 2006), finger (Kothari et al., 2004; Kothari-Chajer et al., 2008) and kodo millets (Kothari-Chajer et al., 2008), improved the quality of response.

It is known that some heavy metals play important roles in the regeneration of plant tissue culture (Purnhauser and Gyulai, 1993). Besides $\mathrm{Cu}$, other metals such as $\mathrm{Ag}, \mathrm{Co}, \mathrm{Mn}, \mathrm{Ni}$, and $\mathrm{Zn}$ have been also reported to stimulate morphogenesis (Roustan et al., 1989; Purnhauser and Gyulai, 1993; Kothari et al., 2004; Kothari-Chajer et al., 2008).

The basis of the positive effect of copper in plant morphogenesis is still not clear. According to Purnhauser and Gyulai (1993) some $\mathrm{Cu}$ enzymes might play a major role in plant regeneration, since $\mathrm{Cu}^{2+}$ is a component or activator of many important enzymes that participate in electron transport, protein and carbohydrate biosynthesis, polyphenol metabolism, and so forth. Our results on the effect of copper on callus extension and on the number and development of organized structures (adventitious buds and shoots), may suggest that this metal ion could modulate genes related to regeneration and/or alter the level or activity of endogenous growth regulators. Furthermore, adverse effects generated by in vitro culture, such as those caused by excessive ethylene, reactive oxygen species (ROS), and (poly) phenols, could be mitigated by increased copper levels. Other studies may indirectly suggest the importance of copper in plant morphogenesis. The respiration rate in cells under callus proliferation and cell division is normally 
bioRxiv preprint doi: https://doi.org/10.1101/2021.02.24.432794; this version posted February 25, 2021. The copyright holder for this preprint (which was not certified by peer review) is the author/funder, who has granted bioRxiv a license to display the preprint in perpetuity. It is made available under aCC-BY 4.0 International license.

higher (Al-Mayahi, 2014), and enhanced levels of copper may be required, since it plays a key role in the respiration process (Yruela, 2009). Rapid cell division and differentiation require adequate amounts of precursors for cell wall biosynthesis (Prażak and Molas, 2015), where copper metalloenzymes play an important part (Delhaize et al., 2015). The molecular and physiological mechanisms associated with this essential, but potentially toxic, heavy metal, should be further investigated to understand its effect on in vitro plant regeneration.

\section{Conclusions}

To the best of our knowledge, this is the first report on the effect of high concentrations of copper ion on in vitro adventitious regeneration of cucumber. From this study, we conclude that optimized copper sulfate levels in MS basal medium, effectively enhanced shoot organogenesis in one inbred line and two commercial cultivars of cucumber. These findings can be further used for large-scale micropropagation of this species, and in genetic transformation studies, could help improve the regeneration efficiency of transformed cells.

Conflict of interests: The author declare that there is no conflict of interests regarding the publication of this paper.

Acknowledgements: The Author is grateful to the Spanish Agency for International Development Cooperation (Agencia Española de Cooperación Internacional para el Desarrollo, AECID) (Spanish Government) for the PhD fellowship.

\section{References}

Akaike H. 1973. Information theory and an extension of the maximum likelihood principle. In: Proceedings of the 2nd International Symposium on Information Theory. Petrov BN, Caski F (Ed.). Akademiai Kado, Budapest, p. 267-281.

Al-Mayahi AMW. 2014. Effect of copper sulphate and cobalt chloride on growth of the in vitro culture tissues for date palm (Phoenix Dactylifera L.) CV. Ashgar. American Journal of Agricultural and Biological Sciences 9: 6-18. doi:10.3844/ajabssp.2014.6.18

Ali N, Skirvin RM, Splittstoesser WE. 1991. Regeneration of Cucumis sativus from cotyledons of small explants. HortScience 26: 925. doi:10.21273/HORTSCI.26.7.925

Alloway BJ (Ed.). 2013. Heavy metals and metalloids as micronutrients for plants and animals. In: Heavy metals in soils: trace metals and metalloids in soils and their bioavailability. Environmental pollution. 3rd edition, Springer, Dordrecht, Vol. 22, p. 195-209. doi:10.1007/978-94-007-4470-7_7

Ananthakrishnan G, Xia X, Elman C, Singer S, Paris HS, Gal-On A, Gaba V. 2003. Shoot production in squash (Cucurbita pepo) by in vitro organogenesis. Plant Cell Reports 21: 739-746. doi:10.1007/s00299-003-0584-y

Arif N, Yadav V, Singh S, Singh S, Ahmad P, Mishra RK, Sharma S, Tripathi DK, Dubey NK, Chauhan DK. 2016. Influence of high and low levels of plant-beneficial heavy metal ions on plant growth and development. Front. Environ. Sci. 4: 69. doi:10.3389/fenvs.2016.00069

Birch RG. 1997. Plant transformation: problems and strategies for practical application. Annu. Rev. Plant Physiol. Plant Mol. Biol. 48: 297-326. doi:10.1146/annurev.arplant.48.1.297

Broadley M, Brown P, Cakmak I, Rengel Z, Zhao F. 2012. Function of nutrients: micronutrients. In: Marschner's mineral nutrition of higher plants. Marschner P (Ed.). 3rd edition, Academic Press, p. 191-248. doi:10.1016/b978-0-12-384905-2.00007-8

Burza W, Malepszy S. 1995a. Direct plant regeneration from leaf explants in cucumber (Cucumis sativus L.) is free of stable genetic variation. Plant Breeding 114: 341-345. doi:10.1111/j.1439-0523.1995.tb01246.x 
bioRxiv preprint doi: https://doi.org/10.1101/2021.02.24.432794; this version posted February 25, 2021. The copyright holder for this preprint (which was not certified by peer review) is the author/funder, who has granted bioRxiv a license to display the preprint in perpetuity. It is made available under aCC-BY 4.0 International license.

Burza W, Malepszy S. 1995b. In vitro culture of Cucumis sativus L. XVIII. Plants from protoplasts through direct somatic embryogenesis. Plant Cell, Tissue and Organ culture 41: 259-266. doi:10.1007/BF00045090

Chang C, Moll BA, Evenson KB, Guiltinan MJ. 1996. In vitro plantlet regeneration from cotyledon, hypocotyl and root explants of hybrid seed geranium. Plant Cell Tiss. Org. Cult. 45: 61-66. doi:10.1007/BF00043429

Chee PP, Tricoli DM. 1988. Somatic embryogenesis and plant regeneration from cell suspension cultures of Cucumis sativus L. Plant Cell Reports 7: 274-277. doi:10.1007/bf00272541

Chee PP. 1990. High frequency of somatic embryogenesis and recover of fertile cucumber plants. HortScience 25: 792-793. doi:10.21273/HORTSCI.25.7.792

Cohu CM, Pilon M. 2010. Cell biology of copper. In: Cell Biology of Metals and Nutrients. Plant Cell Monographs. Hell R, Mendel R-R. (Ed.). Springer, Berlin, Heidelberg, Vol. 17, p. 55-74. doi:10.1007/978-3-642-10613-2_3

Compton ME, Gray DJ. 1993. Shoot organogenesis and plant regeneration from cotyledons of diploid, triploid, and tetraploid watermelon. J. Amer. Soc. Hort. Sci. 118: 151-157. doi:10.21273/jashs.118.1.151

Dahleen LS. 1995. Improved plant regeneration from barley callus cultures by increased copper levels. Plant Cell Tiss. Org. Cult. 43: 267-269.

Delhaize E, Schachtman D, Kochian L, Ryan PR. 2015. Mineral nutrient acquisition, transport, and utilization. In: Biochemistry \& molecular biology of plants. Buchanan BB, Gruissem W, Jones RL (Ed.), American Society of Plant Biologists. 2nd edition, Wiley Blackwell, Chichester, West Sussex, p. 1101-1131.

Den Nijs APM, Custers JBM. 1990. Introducing resistances into cucumbers by interspecific hybridization. In: Biology and utilization of the cucurbitaceae. Bates DM, Robinson RW, Jeffrey C (Ed.). Cornell University Press, Ithaca, NY, p. 382- 396. doi:10.7591/9781501745447-033

Ellul P. 2002. Morfogénesis in vitro y obtención de plantas transgénicas de sandía (Citrullus lanatus [Thunb.] Matsum. \& Nakai.). PhD Thesis. Universidad Politécnica de Valencia.

Fox J, Monette G. 1992. Generalized collinearity diagnostics. Journal of the American Statistical Association 87: 178-183. doi:10.1080/01621459.1992.10475190

Fox J, Weisberg S. 2011. An $\{R\}$ companion to applied regression. 2nd edition, Sage, Thousand Oaks, CA.

Gaba V, Schlarman E, Elman C, Sagee O, Watad AA, Gray DJ. 1999. In vitro studies on the anatomy and morphology of bud regeneration in melon cotyledons. In Vitro Cell. Dev. Biol.-Plant 35: 1-7. doi:10.1007/s11627-999-0001-5

Gambley RL, Dodd WA. 1990. An in vitro technique for the production de novo of multiple shoots in cotyledon explants of cucumber (Cucumis sativus L.). Plant Cell Tiss. Org. Cult. 20: 177-183.

Garcia-Sogo B, Roig LA, Moreno V. 1991. Enhancement of morphogenetic response in cotyledon-derived explants of Cucumis melo induced by copper ion. Acta Hortic. 289: 229-230. doi:10.17660/ActaHortic.1991.289.56

Ghaemi M, Sarrafi A, Alibert G. 1994. The effects of silver nitrate, colchicine, cupric sulfate and genotype on the production of embryoids from anthers of tetraploid wheat (Triticum turgidum). Plant Cell Tiss. Org. Cult. 36: 355-359. doi:10.1007/BF00046093

Grozeva S, Velkov N. 2014. In vitro plant regeneration of two cucumber (Cucumis sativum L.) genotypes: effects of explant types and culture medium. Genetika 46: 485-493. doi:10.2298/GENSR1402485G

Han J-S, Oh D-G, Mok I-G, Park H-G, Kim CK. 2004. Efficient plant regeneration from cotyledon explants of bottle gourd (Lagenaria siceraria Standl.). Plant Cell Rep. 23: 291-296. doi:10.1007/s00299-004-0846-3

He Z, Chen L, Yao W, Dai J. 2008. Recent progress in cucumber (Cucumis sativus) transformation. Transgenic Plant Journal 2: 39-44.

Hinchee MAW, Connor-Ward DV, Newell CA, MCDonnell RE, Sato SJ, Gasser CS, Fischhoff DA, Re DB, Fraley RT, Horsch RB. 1988. Production of transgenic soybean plants using Agrobacterium-mediated DNA transfer. Bio/technology 6: 915-922. doi:10.1038/nbt0888-915

Huang S, Li R, Zhang Z, Li L, Gu X, Fan W, Lucas WJ, Wang X, Xie B, Ni P, Ren Y et al. 2009. The genome of the cucumber, Cucumis sativus L. Nature Genetics 41: 1275-1281. doi:10.1038/ng.475 
bioRxiv preprint doi: https://doi.org/10.1101/2021.02.24.432794; this version posted February 25, 2021. The copyright holder for this preprint (which was not certified by peer review) is the author/funder, who has granted bioRxiv a license to display the preprint in perpetuity. It is made available under aCC-BY 4.0 International license.

11 of 13

Johnson PE. 2019. rockchalk: regression estimation and presentation. R package version 1.8.144. https://CRAN.R-project.org/package=rockchalk.

Kabacoff RI. 2011. $R$ in action: data analysis and graphics with R. Manning Publications Co., Shelter Island, NY, USA.

Kabata-Pendias A, Szteke B. 2015. Trace elements in abiotic and biotic environments. CRC Press/Taylor \& Francis Group, Boca Raton, Florida. doi:10.1201/b18198

Kabata-Pendias A. 2010. Trace elements in soils and plants. 4th edition, CRC Press/Taylor \& Francis Group, Boca Raton, Florida. doi:10.1201/b10158

Kleiber C, Zeileis A. 2008. Applied econometrics with R. Springer-Verlag, New York. doi:10.1007/978-0-38777318-6

Kothari SL, Agarwal K, Kumar S. 2004. Inorganic nutrient manipulation for highly improved in vitro plant regeneration in finger millet-Eleusine coracana (L.) Gaertn. In Vitro Cell. Dev. Biol.-Plant 40: 515-519. doi:10.1079/IVP2004564

Kothari-Chajer A, Sharma M, Kachhwaha S, Kothari SL. 2008. Micronutrient optimization results into highly improved in vitro plant regeneration in kodo (Paspalum scrobiculatum L.) and finger (Eleusine coracana (L.) Gaertn.) millets. Plant Cell Tiss. Org. Cult. 94: 105-112. doi:10.1007/s11240-008-9392-y

Kowalska U, Szafrańska K, Krzyżanowska D, Kiszczak W, Górecki R, Janas K, Górecka K. 2012. Effect of increased copper ion content in the medium on the regeneration of androgenetic embryos of carrot (Daucus carota L.). Acta Agrobot. 65: 73-82. doi:10.5586/aa.2012.060

Kreuger M, van der Meer W, Postma E, Abbestee R, Raaijmakers N, van Holst G-J. 1996. Genetically stable cell lines of cucumber for the large-scale production of diploid somatic embryos. Physiol. Plant. 97: 303-310. doi:10.1034/j.1399-3054.1996.970213.x

Li Y, Sun Y, Luo W, Ni L. 2016. Effects of various explants and hormone combinations on in vitro regeneration in cucumber. Chemical Engineering Transactions 51: 31-36. doi:10.3303/CET1651006

Lin Y-T, Lin C-W, Chung C-H, Su M-H, Ho H-Y, Yeh S-D, Jan F-J, Ku H-M. 2011 . In vitro regeneration and genetic transformation of Cucumis metuliferus through cotyledon organogenesis. HortScience 46: 616-621. doi:10.21273/hortsci.46.4.616

Lou H, Kako S. 1994. Somatic embryogenesis and plant regeneration in cucumber. HortScience 29: 906-909. doi:10.21273/HORTSCI.29.8.906

Malepszy S, Nadolska-Orczyk A. 1983. In vitro culture of Cucumis sativus. I. Regeneration of plantlets from callus formed by leaf explants. Zeitschrift für Pflanzenphysiologie 111: 273-276. doi:10.1016/s0044$328 \times(83) 80086-5$

Malepszy S. 1988. Cucumber (Cucumis sativus L.). In: Biotechnology in Agriculture and Forestry, Crops II. Bajaj YPS (Ed.). Springer-Verlag, Berlin, Heidelberg, Vol. 6, p. 277-293. doi:10.1007/978-3-642-73520-2_13

Migocka M, Malas K. 2018. Plant responses to copper: molecular and regulatory mechanisms of copper uptake, distribution and accumulation in plants. In: Plant micronutrient use efficiency: Molecular and genomic perspectives in crop plants. Hossain MA, Kamiya T, Burritt DJ, Tran L-SP, Fujiwara T (Ed.). Academic Press, p. 71-86. doi:10.1016/B978-0-12-812104-7.00005-8

Miguel, JAF. 2017. Estudios sobre regeneración y transformación genética en pepino (Cucumis sativus L.) vía Agrobacterium tumefaciens. PhD Thesis. Universidad Politécnica de Valencia. doi:10.4995/Thesis/10251/ 90405

Msikita W, Skirvin RM, Juvik JA, Splittstoesser WE, Ali N. 1990. Regeneration and flowering in vitro of 'Burpless Hybrid' cucumber cultured from excised seed. HortScience 25: 474-477. doi:10.21273/HORTSCI.25.4.474

Murashige T, Skoog F. 1962. A revised medium for rapid growth and bio assays with tobacco tissue cultures. Physiologia Plantarum 15: 473-497. doi:10.1111/j.1399-3054.1962.tb08052.x

Nirwan RS, Kothari SL. 2003. High copper levels improve callus induction and plant regeneration in Sorghum bicolor (L.) Moench. In Vitro Cell. Dev. Biol.-Plant 39: 161-164. doi:10.1079/IVP2002385 
bioRxiv preprint doi: https://doi.org/10.1101/2021.02.24.432794; this version posted February 25, 2021. The copyright holder for this preprint (which was not certified by peer review) is the author/funder, who has granted bioRxiv a license to display the preprint in perpetuity. It is made available under aCC-BY 4.0 International license.

Nunes CS, Malmlöf K. 2018. Enzymatic decontamination of antimicrobials, phenols, heavy metals, pesticides, polycyclic aromatic hydrocarbons, dyes, and animal waste. In: Enzymes in human and animal nutrition: principles and perspectives. Nunes CS, Kumar V (Ed.). Academic Press, p. 331-359. doi:10.1016/B978-012-805419-2.00017-4

Plader w, Burza w, Malepszy S. 2007. Cucumber. In: Biotechnology in Agriculture and Forestry. Transgenic Crops IV. Pua EC, Davey MR (Ed.). Springer-Verlag, Berlin Heidelberg, Germany, Vol. 59, p. 181-199. doi:10.1007/978-3-540-36752-9_10

Prażak R, Molas J. 2015. Effect of copper concentration on micropropagation and accumulation of some metals in the Dendrobium kingianum Bidwill Orchid. J. Elem. 20: 693-703. doi:10.5601/jelem.2014.19.4.748

Punja ZK, Abbas N, Sarmento GG, Tang FA. 1990a. Regeneration of Cucumis sativus var. sativus and C. sativus var. hardwickii, C. melo, and C. metuliferus from explants through somatic embryogenesis and organogenesis. Plant Cell Tiss. Org. Cult. 21: 93-102. doi:10.1007/BF00033427

Punja ZK, Tang FA, Sarmento GG. 1990b. Isolation, culture and plantlet regeneration from cotyledon and mesophyll protoplasts of two pickling cucumber (Cucumis sativus L.) genotypes. Plant Cell Reports 9: 61-64. doi:10.1007/BF00231549

Purnhauser L, Gyulai G. 1993. Effect of copper on shoot and root regeneration in wheat, triticale, rape and tobacco tissue cultures. Plant Cell Tiss. Org. Cult. 35: 131-139. doi:10.1007/BF00032962

Purnhauser L. 1991. Stimulation of shoot and root regeneration in wheat Triticum aestivum callus cultures by copper. Cereal Res. Commun. 19: 419-423.

R Core Team. 2018. R: A language and environment for statistical computing. R Foundation for Statistical Computing, Vienna.

Raharjo SHT, Punja ZK. 1994. Regeneration of plantlets from embryogenic suspension cultures of pickling cucumber (Cucumis sativus L. cv. Endeavor). In Vitro Cell. Dev. Biol. 30: 16-20. doi:10.1007/BF02632114

Roustan JP, Latche A, Fallot J. 1989. Stimulation of Daucus carota somatic embryogenesis by inhibitors of ethylene synthesis: cobalt and nickel. Plant Cell Reports 8: 182-185. doi:10.1007/bf00716836

Sahrawat AK, Chand S. 1999. Stimulatory effect of copper on plant regeneration in indica rice (Oryza sativa L.). J. Plant Physiol. 154: 517-522. doi:10.1016/s0176-1617(99)80292-2

Schwarz G. 1978. Estimating the dimension of a model. The Annals of Statistics 6: 461-464. doi:10.1214/aos/1176344136

Selvaraj N, Vasudevan A, Manickavasagam M, Ganapathi A. 2006. In vitro organogenesis and plant formation in cucumber. Biologia plantarum 50: 123-126. doi:10.1007/s10535-005-0085-7

Selvaraj N, Vasudevan A, Manickavasagam M, Kasthurirengan S, Ganapathi A. 2007. High frequency shoot regeneration from cotyledon explants of cucumber via organogenesis. Scientia Horticulturae 112: 2-8. doi:10.1016/j.scienta.2006.12.037

Seo SH, Bai DG, Park HY. 2000. High frequency shoot regeneration from leaf explants of cucumber. J. Plant Biotech. 2: 51-54.

Shahbaz M, Pilon M. 2019. Conserved Cu-microRNAs in Arabidopsis thaliana function in copper economy under deficiency. Plants 8: 1-14. doi:10.3390/plants8060141

Singh M, Kaur M, Bakshi M, Kapurwan S, Kumar A. 2017. Copper and zinc induced amelioration of in vitro multiplication of Dendrocalamus strictus (Roxb.) Nees. Indian Journal of Forestry 40: 181-184.

Sinha A, Jain R, Kachhwaha S, Kothari SL. 2010. Optimization of the level of micronutrient copper in the culture medium improves shoot bud regeneration in Indian Ginseng [Withania somnifera (L.) Dunal]. Natl. Acad. Sci. Lett. 33: 11-16.

Souza FVD, Garcia-Sogo B, Souza AS, San-Juán AP, Moreno V. 2006. Morphogenetic response of cotyledon and leaf explants of melon (Cucumis melo L.) cv. Amarillo Oro. Brazilian Archives of Biology and Technology 49: 21-27. doi:10.1590/S1516-89132006000100003 
bioRxiv preprint doi: https://doi org/10.1101/2021.02 24.432794 this version posted February 25, 2021. The copyright holder for this preprint (which was not certified by peer review) is the author/funder, who has granted bioRxiv a license to display the preprint in perpetuity. It is made available under aCC-BY 4.0 International license.

Staba EJ. 1969. Plant tissue culture as a technique for the phytochemist. In: Recent advances in phytochemistry. Seikel MK, Runcekles VC (Ed.). Appleton-Century-Crofts, New York, Vol. 2, p. 75-106.

Tomar PR, Dixit AR, Jaiwal PK, Dhankher OP. 2015. Engineered plants for heavy metals and metalloids tolerance. In: Genetic Manipulation in Plants for Mitigation of Climate Change. Jaiwal PK, Singh RP, Dhankher OP (Ed.). Springer, New Delhi, p. 143-168. doi:10.1007/978-81-322-2662-8_7

Tripathi DK, Singh S, Singh S, Mishra S, Chauhan DK, Dubey NK. 2015. Micronutrients and their diverse role in agricultural crops: advances and future prospective. Acta Physiol. Plant. 37: 1-14. doi:10.1007/s11738-0151870-3

Trulson AJ, Shahin EA. 1986. In vitro plant regeneration in the genus Cucumis. Plant Science 47: $35-43$. doi:10.1016/0168-9452(86)90008-7

Venables WN, Ripley BD. 2002. Modern applied statistics with S. 4d edition, Springer, New York. doi:10.1007/978-0-387-21706-2

Wang S-L, Ku SS, Ye X-G, He C-F, Kwon SY, Choi PS. 2015. Current status of genetic transformation technology developed in cucumber (Cucumis sativus L.). Journal of Integrative Agriculture 14: 469-482. doi:10.1016/S2095-3119(14)60899-6

Wehner TC, Locy RD. 1981. In vitro adventitious shoot and root formation of cultivars and lines of Cucumis sativus L. HortScience 16: 759-760.

Yee TW. 2019. VGAM: Vector generalized linear and additive models. R package version 1.1-1.

Yin Z, Bartoszewski G, Szwacka M, Malepszy S. 2005. Cucumber transformation methods - the review. Biotechnologia 1: 95-113.

Yruela I. 2005. Copper in plants. Braz. J. Plant Physiol. 17: 145-156. doi:10.1590/S1677-04202005000100012

Yruela I. 2009. Copper in plants: acquisition, transport and interactions. Functional Plant Biology 36: 409-430. doi:10.1071/FP08288

Ziv M, Gadasi G, 1986. Enhanced embryogenesis and plant regeneration from cucumber (Cucumis sativus L.) callus by activated charcoal in solid/liquid double-layer cultures. Plant Sci. 47: 115-122. doi:10.1016/01689452(86)90058-0 